\title{
カルボキシルエステラーゼの分子多様性と種差
}

\author{
細川 正清

\section{Multiplicity and Species Differences of Carboxylesterase Isozymes in Mammals and Humans}

\author{
Masakiyo Hosokawa \\ Laboratory of Biochemical Pharmacology and Toxicology, \\ Faculty of Pharmacutical Sciences, Chiba University, Chiba
}

\begin{abstract}
Summary: Liver microsomal carboxylesterases (E.C. 3.1.1.1) function in the hydrolysis of a wide variety of endogenous and xenobiotic compounds, and play an important role in drug and lipid metabolism in many mammalian species. Multiple isozymes of liver microsomal carboxylesterases exist in various animal species, and the enzyme is involved in the metabolic activation of ester- and amide-type prodrugs. In the present study, twenty-seven carboxylesterase isozymes were purified to electrophoretic homogeneity from liver microsomes of ten mammalian species and humans, and their physical, enzymological and immunological properties were compared with each other. And also we tried to compare the primary structure of carboxylesterase isozymes in various animal species and humans using cDNA cloning and analysis. The carboxylesterase isozymes from various species examined here showed considerable similarities in physicochemical and immunochemical properties, but not similar in substrate specificity. The deduced amino acid sequence of the clone possessed many structural characteristics that are highly conserved among rat RL1, RH1, RHlec, RS1, RS2, mouse ML1, MH1, MS1, guinea pig GP, beagle dog D1 and human HU1, including active site sequence (GESAGG, NKQEXG, GDHXD), and four cysteines that may be involved in the specific disulfide bond. It is well known that proteins that are retained in the endoplasmic reticulum (ER) lumen contain the retention signal at their carboxy- terminal of the tetrapeptide (KDEL-COOH). The seven carboxylesterase clones (RL1, RH1, RHlec, MH1, GP, D1 and HU1) also contained an ER-retention signal of carboxylesterase (HXEL), and three clones (RS1, RS2, MS1) did not contain this peptide. When clone was expressed in COS7 and V79 cells, the plasmid-coded protein was retained. The cells expressing carboxylesterase is very high activity towards xenobiotic ester and amide. Site-specific mutation of the three amino acid residues of catalytic triad (Ser203 to Thr203, Glu335 to Ala 335, or His 448 to Ala448) greatly reduced the carboxylesterase activity. In conclusion, liver microsomal carboxylesterase in mammals and humans are closely involved in drug and lipid metabolism in the endoplasmic reticulum, and it is noteworthy that the isozymes from various species examined here showed considerable similarities in amino acid sequences, but not similar in substrate specificity. These reasons may be due to the variances of substrate binding site.
\end{abstract}

Key words: Carboxylesterase, Serin hydrolase, cDNA cloning, Species differences, Molecular evolution, Individual differences, Nomenclature, Classification

\section{はじめに}

近年，バイオアベイラビリティーの改善や副作用の軽 減を目的に多くのプロドラッグが合成され，臨床で使用 されている.これらのプロドラッグの中で, エステルお よびアミド型プロドラッグの代謝活性化の過程において もっとも重要な役割を果たしている酵素が, カルボキシ ルエステラーゼ (CES) である. 本酵素は, 活性中心
にセリン残基を有するセリン水解酵素のスーパーファミ リーに属しており, エステル, アミドやチオエステル結 合を含む化合物を効率よく加水分解することから, 上述 したプロドラッグのみならず多くの医薬品, 殺虫剤, 環 境化学物質や食品添加物等の生体外暴物の解瑇や代謝活 性化に関与していることが明らかになっている1-7). ま た，本酵素は生体内の長鎖アシル化合物の代謝にも関与 していることから, 生体外異物のみならず生体内の脂質

千葉大学 薬学部 薬物学研究室 $\overline{\mathbf{T}} 263-8522$ 千葉市稲毛区弥生町 1-33 
代謝においても重要な役割を果たしているものと考えら れている. 著者は大学院の博士課程で CES と出会って から今日に至る屯で, 本酵素の分子構造, 機能的役割, 分子進化および発現調節機構に着目して研究を続けてき た. 本稿では，著者のこれまで行ってきた研究を中心に， $\mathrm{CES}$ の分子多様性と哺乳動物種属間の差異について述 べるとともに, 最近我々の研究室で得られた, ヒト CES の発現調節機構の個人差に関しても紙面の許すか ぎり紹介したい。

\section{カルボキシルエステラーゼが触媒する酵素反 応}

CES は, カルボン酸のエステルを水解する酵素とし てEC3.1.1.1 の番号が付けられており, カルボキシルエ ステルの加水分解反応を触媒する酵素として知られてい る、しかしながら, 本酵素の触媒する反応は, カルボキ シルエステル結合にかぎらず，アミド結合やチオエステ ル結合にいたるまで多岐にわたっており，このことが本 酵素の生体内での役割の解明を困難にする原因の一つに もなっている ${ }^{1-8)}$. 本酵素の触媒する反応は, 酵素のセ リン残基の- $\mathrm{OH}$ と基質のアシル基がアシルー酵素結合 体を形成し, 最初の生成物が離れた後, 第 2 の基質で ある $\mathrm{H}_{2} \mathrm{O}$ にアシル基を転移する典型的なピンポン bi-bi 機構で加水分解を触媒しているものと考えられている (Fig. 1)。一般的にこのようなピンポン bi-bi 機構の場
合, 酵素の反応速度式は複雑になるが，CES の場合は 2 番目の基質が反応液中に含まれている $\mathrm{H}_{2} \mathrm{O}$ であるこ とから近似的に単基質の場合と同様に Michaelis-Menten の式に当てはめることが可能である. また, 本酵素 の基質特異性はカルボキシル基に隣接した原子 $(\mathrm{O}, \mathrm{N}$ もしくは S) により特異性が決定するとはかぎらず，む しろ Fig. 1 に示したような R, R'や R"の構造に依存す ることが，これまでに精製された多くの CES で証明さ れている1-8).

一般的には, 酵素の触媒反応の特徵の一つとして特異 性が高いことがあげられておうり「酵素」とは特異的な 活性化能を持つことにより触媒として働く性質を有する タンパク質であると定義されている9 ${ }^{9}$. しかしながら興 味深いことに, 今日薬物代謝酵素に分類されている酵素 の多くがCES 上同様に広い基質特異性を示しており， 特異的な活性化能という酵素の定義からは大きくはずれ ている.このことは, 薬物 (異物) 代謝酵素自体が他の 生体内の物質代謝を触媒する酵素とは異なり, 進化の初 期の時点で外来性の異物（食物あるいは食物と同時に生 体内に取り込まれる物質）を代謝する酵素として分化 し，独自の分子進化を遂げてきた結果であるものと考え られる.

\section{カルボキシルエステラーゼの組織内分布}

CES は，哺乳動物のほとんどすべての組織に存在し，

A) Carboxylester
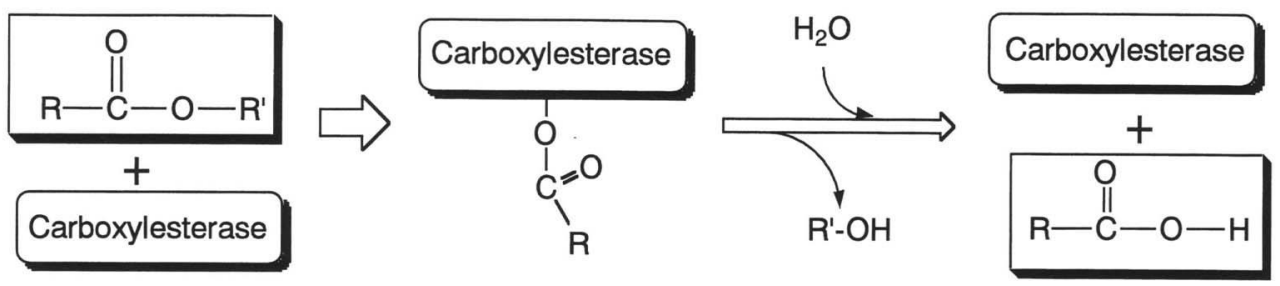

B) Carboxyl amide
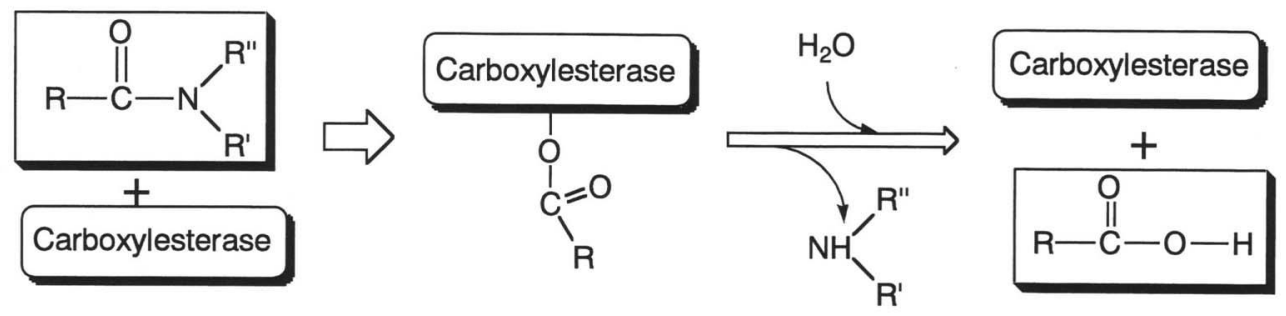

C) Carboxythioester
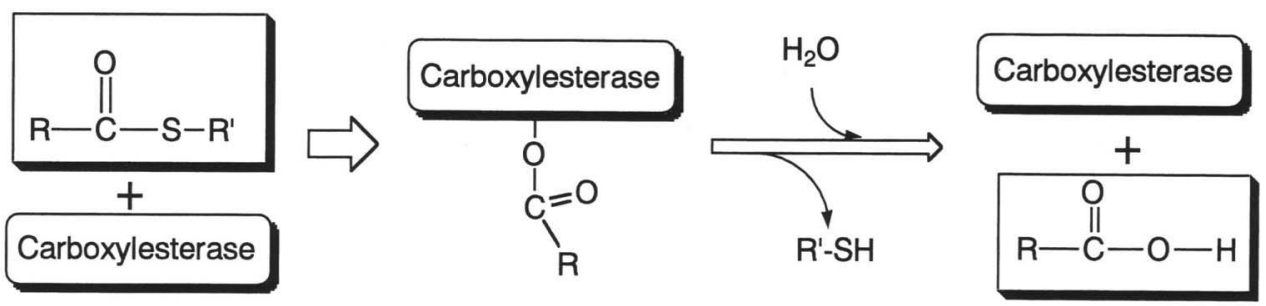

Fig. 1 The catalytic mechanism of carboxylesterases 
(A)

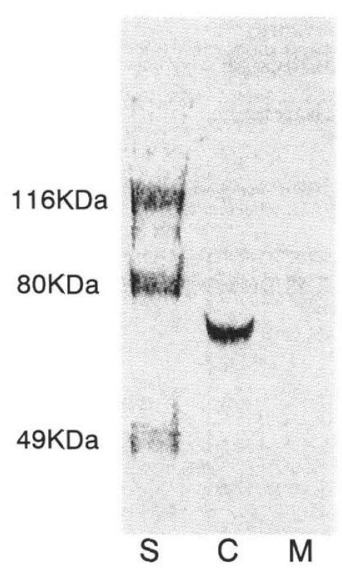

(B) Human Liver (anti-HU1)

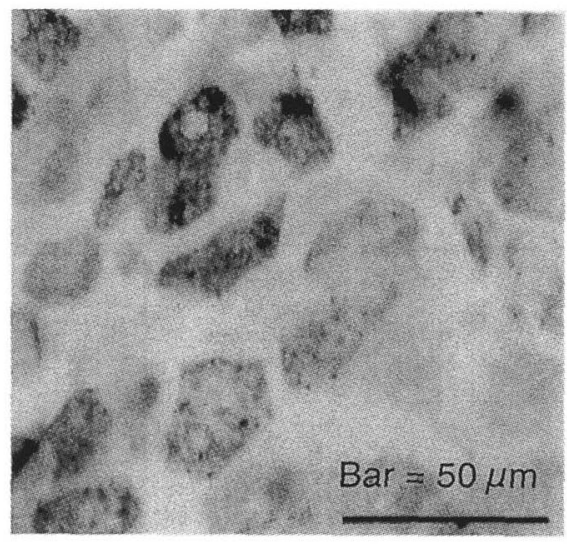

Human Brain (anti-HU1)

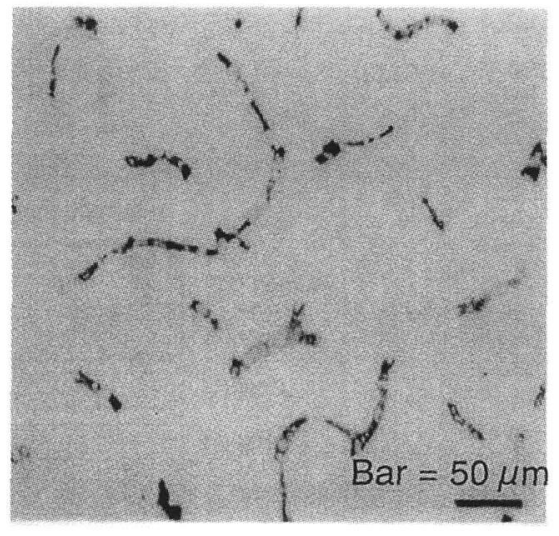

Fig. 2 Immunoblot analysis and immunostaining of human liver and brain tissues with anti-HU1 antibody (A) Immunoblot analysis M; membrane fraction, C; cytosol, S; standard

(B) Immunostaining

肝においてもっとも高い水解活性を有しており, 腎尿細 管, 小腸の上皮細胞, 血液, 精巣, 脂肪組織や中枢神経 系にも発現している10,11)、ヒトに抢いてもCES は, 肝 をはじめとして様々な蔵器で見いだされている ${ }^{12,13)}$ 。し かしながら, これらの加水分解酵素すべてが CES であ ると証明された訳ではないので，それぞれの組織に発現 する加水分解酵素についての詳細な検討が必要である. また最近, 千葉大学医学部との共同研究の結果, ヒト脳 に扔いて肝臓と諸性質のきわめて類似したエステラーゼ の存在を確認し ${ }^{12)}$, 肝臓と類似の CES が中枢神経系に 扔いても発現していることを見いだした。ささらにエステ ラーゼの特異抗体を用いた免疫組織科学的手法により,

この酵素が主に脳毛細血管内皮細胞に局在していること も初めて明らかにした（Fig. 2)。一般的に脳毛細血管 内皮細胞が血液脳関門の働きをしていることが知られて いることから，CES が薬物の脳移行性に重要な働きを している可能性が考えられ，ヒ卜肝と脳ではそれぞれ異 なった役割を果たしているものと考えられた. 現在, こ のヒト脳 CES については CDNA クローニングを行って おり, 約 $1.6 \mathrm{Kbp}$ のヒト脳 CES をコードするものと考 えられるクローンを得ているので, 今後さらに脳におけ る役割を明らかにしたい。

\section{カルボキシルエステラーゼの基質特異性と種 差}

エステルやアミド型薬物の生体内動態を考慮して CES の種差を考える場合, 個々の組織に発現する酵素 の特性を考える必要がある。しかしながら，各組織に発 現するCES を含めて種差を考えることは問題を複雑に させることになるため, 哺乳動物種を通じて発現量の高 い肝 CESの種差について, CES に比較的特異性が高く
構造の異なる 4 種の基質を用いて検討した $(\text { Fig. 3 })^{3)}$. ここではエステル型基質として $p$-nitrophenylacetate 抒 よび malathion，アミド型基質として butanilicaine 扔よ び isocarboxazid を用いたが，いずれの場合にも著しい 種差が認められ，少なくとも肝ミクロソーム画分に扔い てはCES 活性に種差が存在することが明らかとなっ た。 また, 用いた基質により種差が異なるという興味深 い結果が得られたことから，哺乳動物種間で質的または 量的に異なるCES アイソザイムの存在する可能性が示 唆された.

つぎにこれら 10 種の哺乳動物およびヒト肝ミクロソ 一ム画分を用いて, ラットから精製した 3 種の CES ア イソザイム（RL1, RL2, RH1）の特異抗体との免疫交 叉性をWestern blot 法によって調べたところ，ラット の 3 種のアイソザイム間で明らかな差異が認められ た2,3).すなわち, 抗 RL1 抗体を用いた場合にはラット の他にマウス, 八ムスター，モルモットにバンドが認め られたが，抗 RL2 抗体では分子量 6 万付近でラットの みに染色バンドがみられた。 しかしながら抗 RH1 抗体 を用いたところ，すべての動物種で分子量 6 万前後の 部分に染色バンドが認められことから，ラット抗 RH1 抗体と免疫交叉性を示し, サブユニット分子量の等しい タンパクが他の哺乳動物種の肝ミクロソーム画分にも存 在することが明らかとなった。 そこで, 用いた哺乳動物 種およびヒト肝ミクロソーム画分より CES の精製を行 ったところ, 10 種の哺乳動物およびヒト肝ミクロソー ム画分から 26 種の CES の精製に成功した $2,3,14,15)$. Table II に示したように, これらのCESアイソザイムは 分子量は類似しているが $(57-64 \mathrm{kDa})$, 等電点につい ては，大きな差異が認められたことから構成するアミノ 酸残基の違いが示唆された。 また，ほとんどのアイソザ 

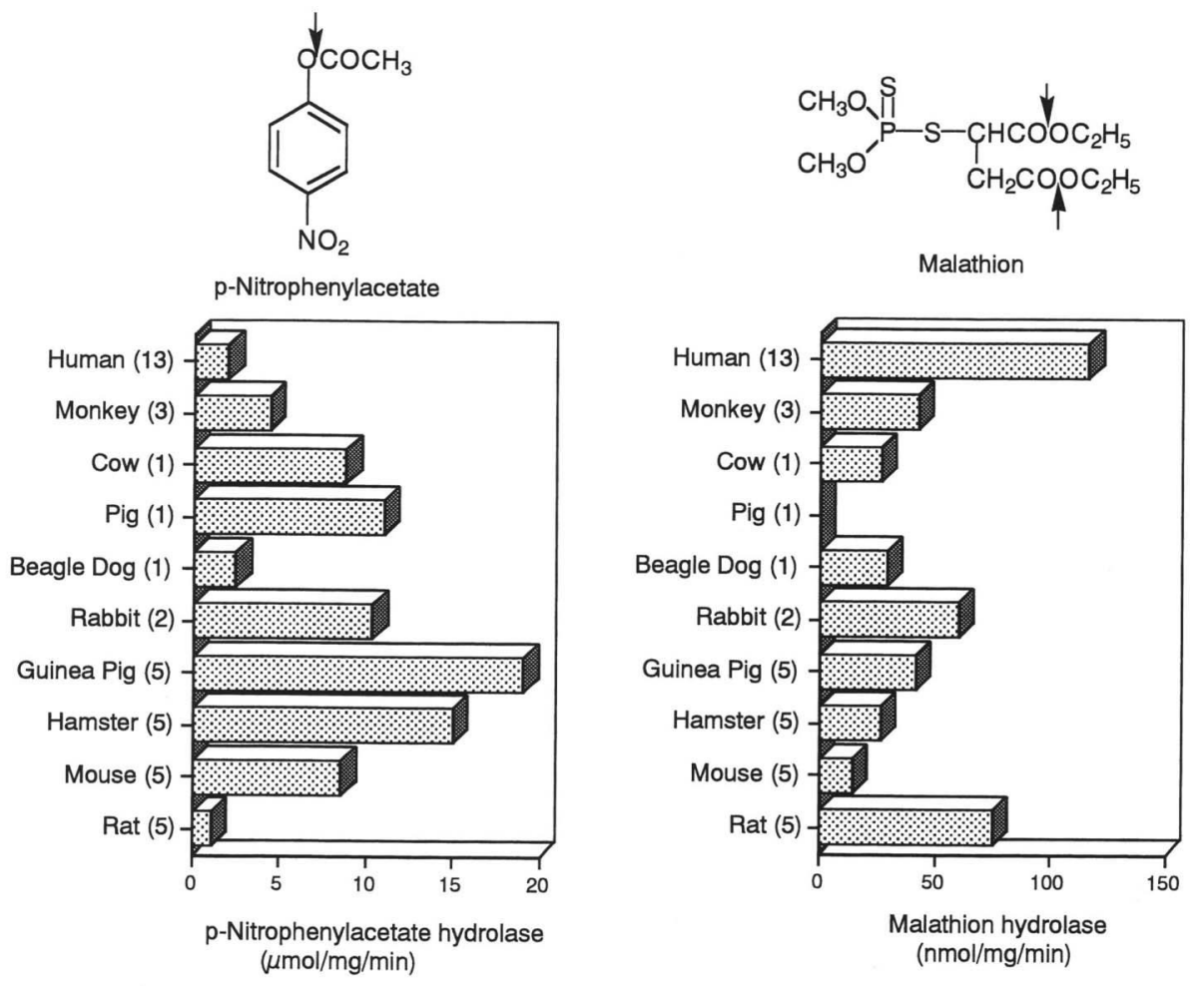

Fig. 3 1: Comparison of liver microsomal carboxylesterase activity in various mammals and humans

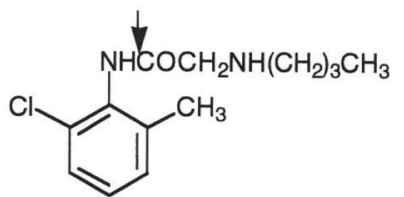

Butanilicaine

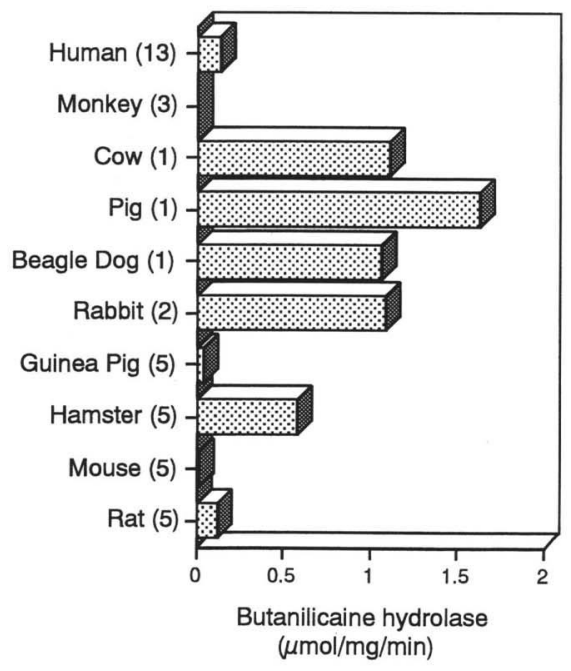

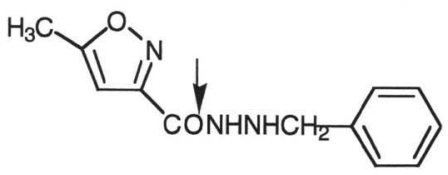

Isocarboxazid

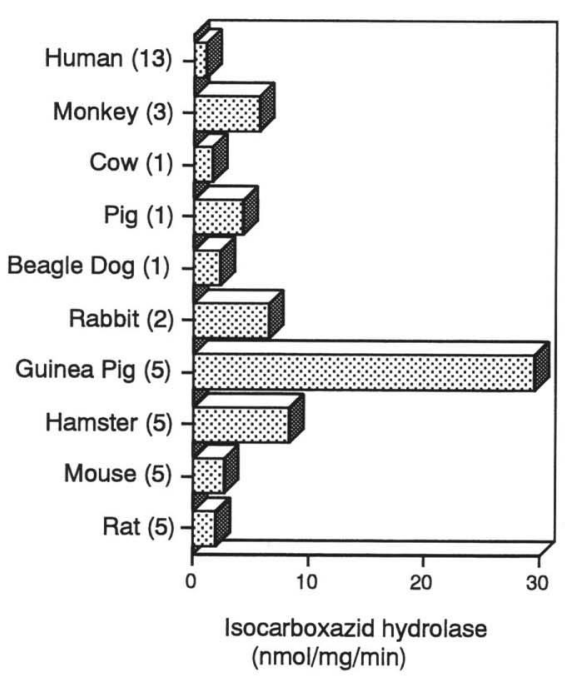

Fig. 3 2: Comparison of liver microsomal carboxylesterase activity in various mammals and humans

イムが ConA アフィニティーカラムに吸着し， $\alpha$ メチ ルマンノシドで溶出されることから, 肝ミクロソームに 局在するCESアイソザイムは，アスパラギン結合の八 イマンノース型糖鎖を持つ可能性が示唆された. さら
に,これらの CES の $\mathrm{N}$-末端アミノ酸配列を気相型プ ロテインシークエンサーを用いて調べたところ, カニク イザルから得られた CES MK2 を除いて, 高い相同性 が認められた ${ }^{3,14}$. また，これらのアイソザイムの免疫 
Table I Comparison of the physical properties of carboxylesterase isozymes

\begin{tabular}{|c|c|c|c|c|}
\hline Species & $\begin{array}{l}\text { Trivial } \\
\text { name }\end{array}$ & $\begin{array}{l}\text { Subunit } \\
\text { (M.W.) }\end{array}$ & $\mathrm{pI}$ & $\begin{array}{l}\text { ConA- } \\
\text { Affinity }\end{array}$ \\
\hline \multirow[t]{7}{*}{ Rat } & RH1 & $58 \mathrm{KDa}$ & 6.0 & + \\
\hline & RL1 & $61 \mathrm{KDa}$ & 6.5 & + \\
\hline & RL2 & $61 \mathrm{KDa}$ & 5.5 & + \\
\hline & RL3 & $61 \mathrm{KDa}$ & 5.0 & + \\
\hline & RL4 & $60 \mathrm{KDa}$ & 4.6 & - \\
\hline & RHlec & $58 \mathrm{KDa}$ & 6.0 & + \\
\hline & RLlec & $60 \mathrm{KDa}$ & 4.7 & - \\
\hline \multirow[t]{4}{*}{ Mouse } & MH1 & $60 \mathrm{KDa}$ & 5.8 & + \\
\hline & ML1 & $59 \mathrm{KDa}$ & 5.9 & + \\
\hline & ML2 & $60 \mathrm{KDa}$ & 5.1 & + \\
\hline & ML3 & $60 \mathrm{KDa}$ & 4.7 & - \\
\hline \multirow[t]{2}{*}{ Hamster } & $\mathrm{H} 1$ & $58 \mathrm{KDa}$ & 5.7 & + \\
\hline & HL1 & $58 \mathrm{KDa}$ & 6.0 & + \\
\hline \multirow[t]{3}{*}{ Guinea Pig } & GPH1 & $57 \mathrm{KDa}$ & 5.3 & + \\
\hline & GPL1 & $64 \mathrm{KDa}$ & 5.9 & + \\
\hline & GPL2 & $61 \mathrm{KDa}$ & 5.6 & + \\
\hline \multirow[t]{2}{*}{ Rabbit } & RB1 & $62 \mathrm{KDa}$ & 5.5 & + \\
\hline & $\mathrm{RB} 2$ & $60 \mathrm{Kda}$ & 4.7 & + \\
\hline Dog & D1 & $60 \mathrm{KDa}$ & 5.0 & + \\
\hline Pig & $\mathrm{P} 1$ & $\begin{array}{c}58 \mathrm{~K}- \\
62 \mathrm{KDa}\end{array}$ & $5.2-5.4$ & + \\
\hline Cow & $\mathrm{B} 1$ & $59 \mathrm{KDa}$ & 6.0 & + \\
\hline \multicolumn{5}{|l|}{ Monkey } \\
\hline \multirow[t]{2}{*}{ Cynomolgus } & MK1 & $60 \mathrm{KDa}$ & 5.5 & + \\
\hline & MK2 & $63 \mathrm{KDa}$ & 4.7 & + \\
\hline \multirow[t]{2}{*}{ Rhesus } & RMK1 & $60 \mathrm{KDa}$ & 5.6 & + \\
\hline & RMK2 & $63 \mathrm{KDa}$ & 4.7 & + \\
\hline \multirow[t]{3}{*}{ Human } & HU1 & $61 \mathrm{KDa}$ & 5.6 & + \\
\hline & HU2 & $61 \mathrm{KDa}$ & 5.4 & + \\
\hline & HU3 & $61 \mathrm{KDa}$ & 4.3 & + \\
\hline
\end{tabular}

交叉性についてウエスタンブロット法を用いて調べたと ころ，ラット以外の動物種ではカニクイザル MK2，ア カゲザル RMK2 を除いてすべて RH1 と免疫交叉性を 示し，これらの染色バンドはすべて肝ミクロソーム画分 で認められたものと移動度が一致したことから，ミクロ ソーム画分で RH1 と交叉性を示したタンパクは CES であることが証明されだ,13)。次に Table II に示したよ うに，これらのCESアイソザイムの基質特異性を調べ たところ，アイソザイム間で著しい差異が認められただ けではなく基質間でも大きな差がみられた。 また，これ らの精製酵素を用いて，プロドラッグとして現在用いら れている CPT-11 の水解活性打よび発癌プロモーター として知られているフォロボールエステルである TPA の水解活性を調べたところ, 哺乳動物種間で大きな差異 がみられた ${ }^{14-16)}$. CPT-11 は肝ミクロソーム画分の CES の加水分解により活性代謝物である SN-38 に代謝 活性化されるので，これらのCESアイソザイム間での 差異が代謝の種差に関与している可能性も示唆された.
また, 発癌プロモーターのTPA の水解活性に関して は,これまで用いた基質の中で特異性がもっとも高いこ とから，本酵素の基質特異性を解明するために有用であ るものと考えられた.

このように肝 CES 活性には大きな種差が認められた が, これら CESアイソザイムの分子量， N-末端アミ， 酸配列や免废交叉性に関しては大きな違いは認められな かったことから, 基質特異性に関与する領域の解明が必 要と考えられる.

\section{カルボキシルエステラーゼの誘導の種差}

これまで実験小動物を含めた肝 CES の制御機構の研 究から, 本酵素は性ホルモン2,17), 副腎皮質ホルモン18), 脳下垂体ホルモン19)などによりアイソザイム間で異な った制御を受けていることが明らかとなってきた。ささら にCES は,フェノバルビタール2,20,21)をはじめ, 多く の化合物により酵素誘導をうけるが21,22)，最近では，ぺ ルオキシソーム増殖剤による誘導も明らかになっ た23-25). しかしながらこれらの CES 誘導には, 種差が 存在しており,フェノバルビタールやペルオキシソーム 増殖薬を用いた場合，哺乳動物種間で大きな差異が認め られた ${ }^{24)}$ 。この中で, ペルオキシソーム増殖薬として 用いたプラスチック可塑剤であるdi (2-ethylhexyl) phthalate は, 環境化学物質としてヒトの生活環境に多 く用いられているので，ヒトでの誘導の有無を含めて今 後さらに詳細な検討が必要であると考えられる.

さらにラット肝においては, 部分肝摘出法を用いた前 癌病変作製時に, 前癌病変の進行に伴って CES のアイ ソザイム間で異なった量的な変動が認められたことか ら, 発癌過程においても何らかの形で本酵素が制御され ている可能性も考えられ, さらに本酵素の変動が発癌過 程に影響を及ぼす可能性も示唆された ${ }^{16)}$.

しかしながらこれらの検討は CES 含量の変動を調ぺ たものであり, 転写, 翻訳機構を含めた制御機構のメカ ニズムを解明したものではない.今後は CESのゲノム 遺厷子の構造を解明し， 5 '上流域を含めた転写調節領 域および転写調節因子を明らかにすることにより，本酵 素の発現調節機構の種差を解明する必要があるものと考 えられる。

\section{カルボキシルエステラーゼの構造の比較}

近年, 分子生物学の発展に伴い薬物代謝酵素に関して も酵素をコードする遺伝子の cDNA クローニングが行 われてきている. CES に関しても, Takagi ら ${ }^{26)}$ にり 1988年にラット肝 CES の cDNA クローニングに成功 して以来, 徐々にではあるが着実に cDNA クローニン グに成功しつつある ${ }^{27-40)}$. 酵素の遺伝子クローニング 
Table II Catalytic activity of the highly purified carboxylesterase isozymes from liver microsomes of various mammalian species and humans

\begin{tabular}{|c|c|c|c|c|c|c|}
\hline \multirow{2}{*}{ Species } & \multirow{2}{*}{ lsozyme } & \multicolumn{5}{|c|}{ Specific activity ( $\mu$ moles/mg prot./min) } \\
\hline & & PNPA & MALA & BUTA & ISOC & $\mathrm{Pal}-\mathrm{CoA}$ \\
\hline \multirow[t]{6}{*}{ Rat } & RH1 & 44.8 & 0.011 & 3.44 & 0.268 & 0.009 \\
\hline & RL1 & 76.4 & 0.201 & $<0.005$ & $<0.001$ & 0.686 \\
\hline & RL2 & 4.16 & $<0.002$ & $<0.005$ & 0.263 & $<0.001$ \\
\hline & RL4 & 64.9 & N.D. & $<0.005$ & 0.229 & 0.109 \\
\hline & RLlec & 2.12 & N.D. & 0.107 & 0.158 & 0.019 \\
\hline & RHlec & 227 & N.D. & 3.046 & 0.067 & 0.002 \\
\hline \multirow[t]{4}{*}{ Mouse } & MH1 & 62.6 & 0.583 & 55.0 & 6.29 & 0.078 \\
\hline & ML1 & 80.9 & $<0.002$ & 17.2 & 0.088 & 0.051 \\
\hline & ML2 & 6.27 & 0.160 & 4.69 & 0.053 & 0.010 \\
\hline & ML3 & 187 & 0.160 & 6.25 & 0.281 & 0.396 \\
\hline Hamster & $\mathrm{H} 1$ & 100 & 0.131 & 23.5 & 0.03 & 0.069 \\
\hline \multirow[t]{3}{*}{ Guinea Pig } & GPH1 & 98.9 & 1.13 & 2.24 & 3.18 & 0.031 \\
\hline & GPL1 & 288 & 0.982 & 3.70 & 17.7 & 0.214 \\
\hline & GPL2 & 50.5 & $<0.002$ & $<0.005$ & 0.294 & 0.025 \\
\hline Rabbit & $\mathrm{RB} 1$ & 126 & 1.22 & 22.4 & 0.153 & 0.018 \\
\hline Dog & D1 & 112 & 0.118 & 33.6 & 0.060 & 0.044 \\
\hline Pig & $\mathrm{P} 1$ & 327 & 2.13 & 111 & 0.333 & 0.089 \\
\hline Cow & $\mathrm{B} 1$ & 90.9 & 0.084 & 2.71 & 0.039 & $<0.001$ \\
\hline Monkey & MK1 & 79.4 & 0.992 & 0.618 & 0.198 & 0.036 \\
\hline (Cynomolgus) & MK2 & 26.4 & 0.647 & $<0.005$ & 2.07 & 0.140 \\
\hline Monkey & RMK1 & 73.0 & N.D. & 3.04 & 0.178 & 0.307 \\
\hline (Rhesus) & RMK2 & 2.54 & N.D. & $<0.005$ & 0.006 & 0.097 \\
\hline \multirow[t]{3}{*}{ Human } & HU1 & 5.84 & 0.467 & 0.483 & 0.010 & 0.025 \\
\hline & HU2 & 3.48 & 0.673 & 0.427 & 0.003 & 0.028 \\
\hline & HU3 & 1.23 & & 0.44 & 7.33 & 0.093 \\
\hline
\end{tabular}

Carboxylesterase isozymes were purified from rat(RL1, RL2, RH1), mouse(MH1, ML1, ML2, ML3), hamster(H1), guinea pig (GPL1, GPL2, GPH1), rabbit (RB1), beagle dog (D1), pig (P1), cow (B1), cynomolgus monkey (MK1, MK2), rhesus monkey and Human (HU1, HU2, HU3) PNPA, p-nitrophenylacetate hydrolase; MALA, malathion hydrolase; BUTA, butanilicaine hydrolase; ISOC, isocarboxazid hydrolase; Pal-CoA, palmitoyl-CoA hydrolase.

N.D., Not determined

を行うことにより，特にCES のように研究人口が少な い酵素においては迅速で正確な情報の入手が可能となる ことから，CESの分類や，反応機構の解明の研究にお いて有用であることが考えられる.

そこで我々の研究室を含めてこれまでに報告されてい る CES の塩基配列から推定されるアミノ酸配列を比較 した. その結果，Table III に示したように，CES の配 列に関しては Cygler ${ }^{41)}$ の提唱したセリン水解醉素の久 一パーファミリーに扔いて catalytic triad を形成してい るものと考えられる Ser203, Glu336, His450近傍やジ スルフィド結合に関与すると考えられるCys 近傍のア ミノ酸配列，さらに oxyanion hole loop 老形成すると考 えられている $\mathrm{Gly}_{124}-\mathrm{Gly}_{125}$ 近傍の配列においては高度 に保存されていることが明らかとなった。また，C一末 端アミノ酸配列についてもラット E1 ( $\mathrm{Sec}$ ) および RS1 マウス ES-N および MS1 を除くアイソザイムは, 全て小胞体膜にKDEL レセプターを介して結合しうる
配列である HXEL（His-Xxx-Glu-Leu-COOH）を有する ことからこれらのCESアイソザイムは小胞体膜に KDEL レセプターを介して結合している可能性が強く 示唆され，この配列を持たない CES は肝臟から血中に 分泌される分泌型の CES である可能性が示された，さ らに, Asn-X-Ser/Thr の配列として知られているアス パラギン型の糖鎖結合可能な配列について調べたとこ ろ，もっとも $\mathrm{N}$-末端に近いアスパラギンAsn61 は，八 ムスターAT-51 を除いてマウスからヒトに至るまで保 存されていたが，C一末端に近いアスパラギンAsn 472 については，八ムスターAT-51，ビーグル犬 D1 および ヒトHU1では認められなかった。この結果はCESの 楉鎖結合可能部位に関しても種差が存在することを示し ており，今後，糖鎖の結合部位と基質特異性の関係につ いて詳細な検討が必要であると考光られる。一方，すで に報告されているヒト CES のゲノム解析の結果 ${ }^{39}$ に当 てはめてエクソン部位を推定したところ, Fig. 4 に示 
Table III Comparison of the conserved motifs in carboxylesterase isozymes

\begin{tabular}{|c|c|c|c|c|c|c|}
\hline Trivial name & Cys (98) & Gly-Gly (123-124) & Ser (203) & Glu (335) & His (448) & C-ternimal \\
\hline HU1 & SEDCLYLNIYTP & IHGGGLMVGAAST & GESAGGE & GINKQEFGWL & VIGDHGDEL & EHIEL \\
\hline $\mathrm{hCE}$ & SEDCLYLNIYTP & IHGGGLMVGAAST & GESAGGE & GINKQEFGWL & VIGDHGDEL & EHIEL \\
\hline $\mathrm{hCEv}$ & SEDCLYLNIYTP & IHGGGLMVGAAST & GESAGGE & GINKQEFGWL & VIGDHGDEL & EHIEL \\
\hline Macrophage & SEDCLYLNIYTP & IHGGGLMVGAAST & GESAGGE & GINKQEFGWL & VIGDHGDEL & EHIEL \\
\hline pI 6.1 & SEDCLYLNVYTP & IHGGGLVVGGAST & GESAGGF & GINKQEFGWI & VIGDHGDEL & KHVEL \\
\hline MH1 & SEDCLYLNIYTP & IHGGGLVVGGAST & GESAGGF & GINKQEFGWI & VIGDHGDEI & EHVEL \\
\hline RH1 & SEDCLYLNVYTP & IHGGGLVVGGAST & GESAGGF & GINKQEFGWI & VIGDHGDEL & KHVEL \\
\hline Dog D1 & SEDCLYLNIYTP & IHGGGLVVGGAST & GESAGGE & GINKQEFGWL & VVGDHGDEL & EHVEL \\
\hline Rabbit1 & SEDCLYLNIYTP & IHGGGLMVGGAST & GESAGGQ & GINQQEFGWI & VIGDHGDEI & EHIEL \\
\hline $\begin{array}{l}\text { ES3 } \\
\text { (Egasin) }\end{array}$ & SEDCLYLNIYTP & IHGGGLVLGGAST & GESAGGE & GIN & VVGDHGDEI & GHTEL \\
\hline Egasyn & SEDCLYLNIYTP & IHGGGLVLGGAST & GESAGGE & GINKQEFGWI & VVGDHGDEI & EHTEL \\
\hline RL1 & SEDCLYLNIYTP & IHGGGLTQGGAST & GESAGGF & GINKQECGWL & VVGDHADDV & HHNEL \\
\hline ML1 & - & - & GESAGGY & GINKQECGWL & VVGDHADDV & YHNEL \\
\hline Hydrolase C & SEDCLYLNIYTP & IHGGGLTQGGAST & GESAGGF & GINKQECGWL & VVGDHADDV & HHNEL \\
\hline Hydrolase B & SEDCLYLNIYTP & IHGGGMTLGGAST & GESAGGF & GINKQECGWL & VVGDHADDL & HHNEL \\
\hline Duck & SEDCLYLNVYTP & IHGGGLVSGPASS & GESAGGV & GVNNCEFGWI & VKADHADEI & KHTDL \\
\hline $\mathrm{E} 1(\mathrm{Sec})$ & SEDCLYLNIYSP & IHGGGLIIGGASP & GESAGGV & GFNKQEFGWI & VQGDHGDEI & EHTEHT \\
\hline Es-N & SEDCLYLNIYSP & IHGGGLVIGGRSP & GESSGGI & GFNKQEFGWI & VEGDHGDEI & EHTEHK \\
\hline RS1 & SEDCLYLNIYSP & IHGGGLIIGGASP & GESAGGV & GFNKQEFGWI & VQGDHGDEI & ЕНТЕHТ \\
\hline MS1 & SEDCLYLNIYSP & IHGGGLVIGGRSP & GESSGGI & GFNKQEFGWI & VEGDHGDEI & ЕHTEHK \\
\hline Rabbit2 & SEDCLYLNIYSP & IHGGGLTMGMASM & GESAGGT & GINNDEYGWI & VRADHGDEV & KHTEL \\
\hline AT51 & SEDCLYLNIYTP & IHGGALVMGMASM & GVSAGGT & GVDSDECGWG & VRADHGDHV & KHSEL \\
\hline ES-male & SEDCLTLNIYSP & IHGGSLRVGSSTS & GNSAGGN & GVTNHEFGWL & AFV-FGGP & VPEEL \\
\hline $46.5 \mathrm{kDa}$ & KFNNILVRVYVP & IHGGGWCVG-SAA & GDSAGGN & DVRAAPLLAD & & LKENL \\
\hline
\end{tabular}

したようにCES は14のエクソンから構成されており， CES アイソザイムのエクソン 1 はシグナルペプチドを コードしている可能性が示された。 また, エクソンの 2 から 7 および12から14にはきわめて高い相同性がみ られ，この領域が種を通じて高度に保存されて他の相同 性が低いこ領域が基質特性の差異に関与している可能性 が考えられた。 また興味深いことに，ラットおよびマウ スの分泌型 CES である E1, RS1, ES-N, MS1 および肝 小胞体膜結合型であるハムスターの AT-51 $1^{37)}$ ，ウサギ の Rabbit $2^{42)}$ に抢いてはエクソン 8 の部分が欠損して いたことから，このエクソン部位が CES の進化の過程 で欠損し，分泌型と肝小胞体膜結合型に分化してきたの ではないかと考えられる.

さらに,これらのcDNAを哺乳動物細胞である COS7 cell に導入発現させて諸性質を検討したところ， 精製 CES の基質特異性とよく一致した。 また，これら の発現タンパクについてWestern blot 法により免疫交 叉性を調べたところ，それぞれの特異抗体にの及交叉性 を示した。しかしながら CoS7 cell での発現は一過性で あるので, 薬物代謝の予測系や代謝活性化の試験に用い るには stable な発現系が必要であるものと考えられる. そこでV79 cell に CES 遺伝子を導入し G418 で選択し たところ，高いエステラーゼ活性を示す細胞を得ること
ができ，さらに $\mathrm{Km}$ 值や阻害剤を用いた検討において も精製酵素と一致したことからこれらの stable な CES 発現細胞を薬物代謝試験や毒性試験に用いること が可能となった.

また部位特異的変異の導入により活性中心を調べたと ころ, catalytic triad を構成しているものと考えられる Ser203, Glu336, His450いずれの部位に関しても, 変異 導入でアミノ酸残基を置換することにより著しく活性が 低下したことから，このアミノ酸残基が CES の catalytic triad を構成しているものと考えられた.

一方, CES の哺乳動物細胞発現系の作製に成功した ので，基質結合部位を調べるために特異性の異なるラッ ト肝 CES アイソザイム RH1 およびRL1 を用いてキメ ラ酵素を作製し, 基質結合領域の解明を試みた。両アイ ソザイムの塩基配列から推定されたアミノ酸配列の差異 を検討したところ, Glu334よりC一末側の領域に差異が 認められたため, Glu334 より $\mathrm{N}$-末端側と C一未端側を 用いたキメラ酵素を作製した. 2 種類のキメラ酵素をコ ードする cDNA RH1 Glu-334 RL1（RH1 E334 RL1）お お よび RL1 Glu-334 RH1（RL1 E334 RH1）を哺乳動物細 胞に発現させたところ, RH1 E334 RL1 は RL1 と同程 度の Palmitoyl-CoA 水解活性を示したのに対し, RL1 E334 RH1 では Palmitoyl-CoA 水解活性は著しく低下 

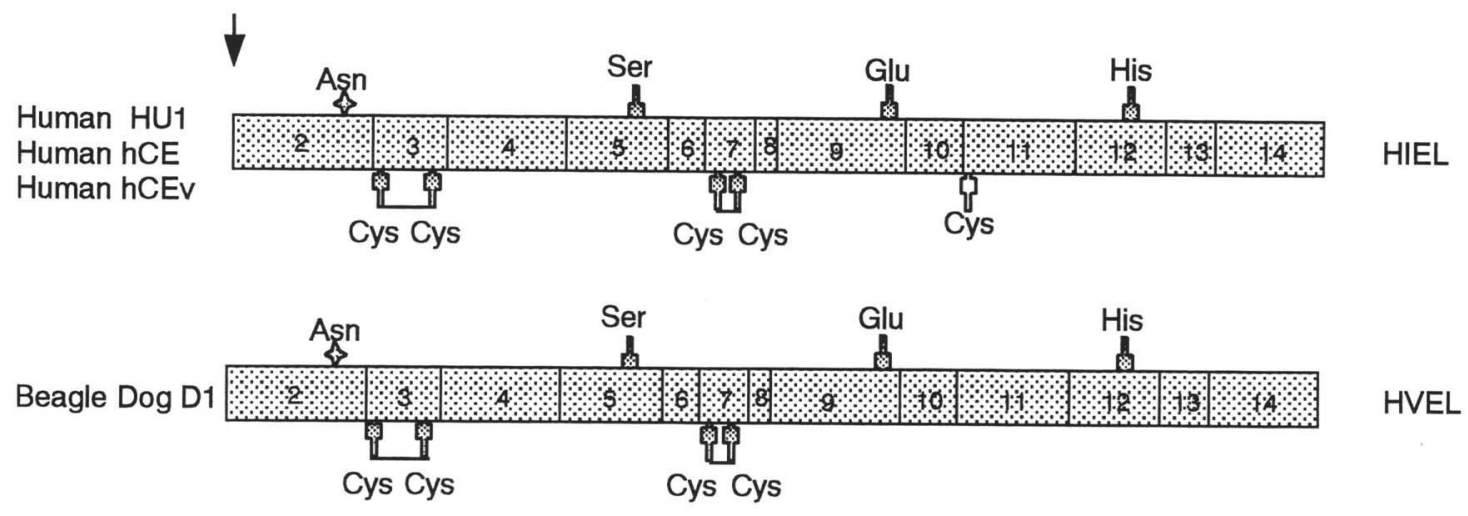

Rat pl 6.1

Rat $\mathrm{RH} 1$

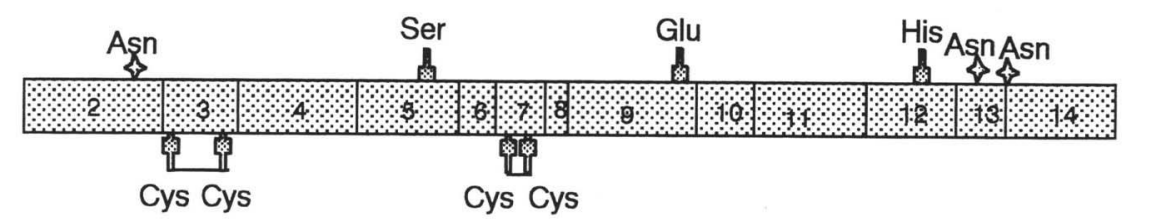

HVEL

Rat RL1



HNEL
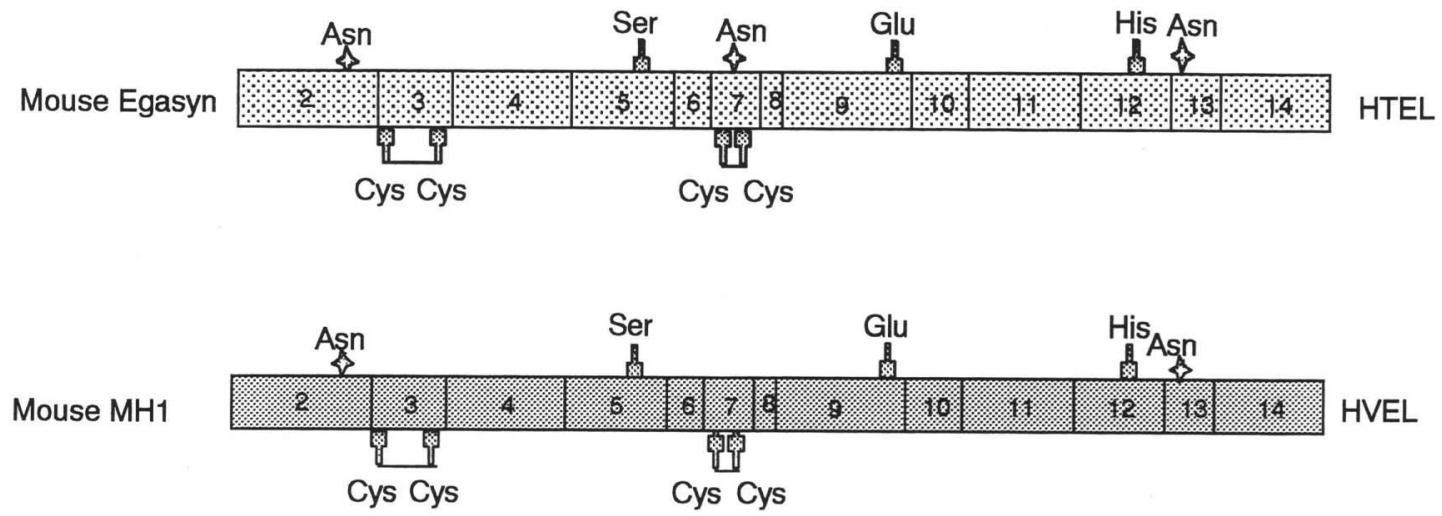

Rat E1

Rat RS1

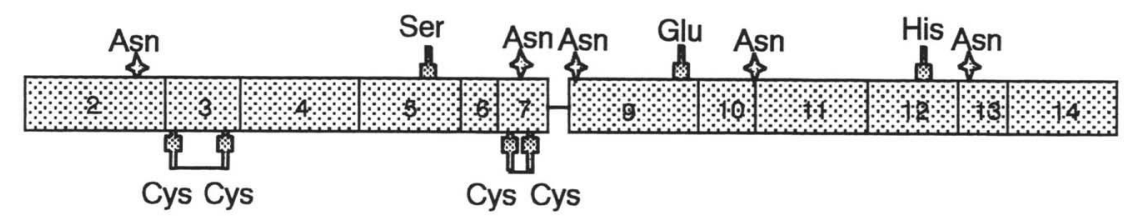

TETHT

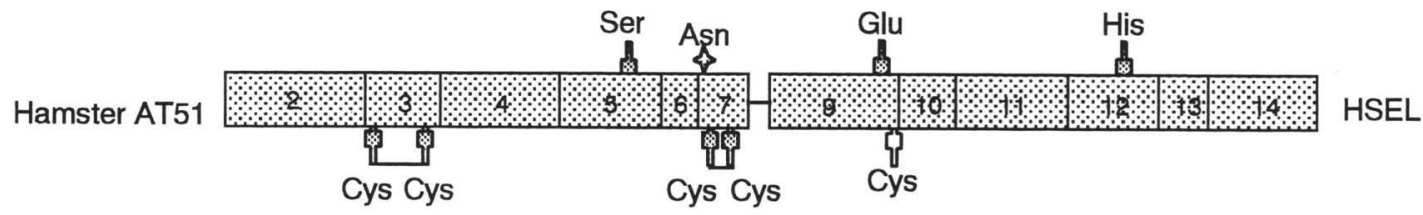

Fig. 4 Diagrammatic comparison of deduced amino acid sequences of rat, mouse, hamster and human carboxylesterase isozymes. Each trivial manes is listed in Table IV 

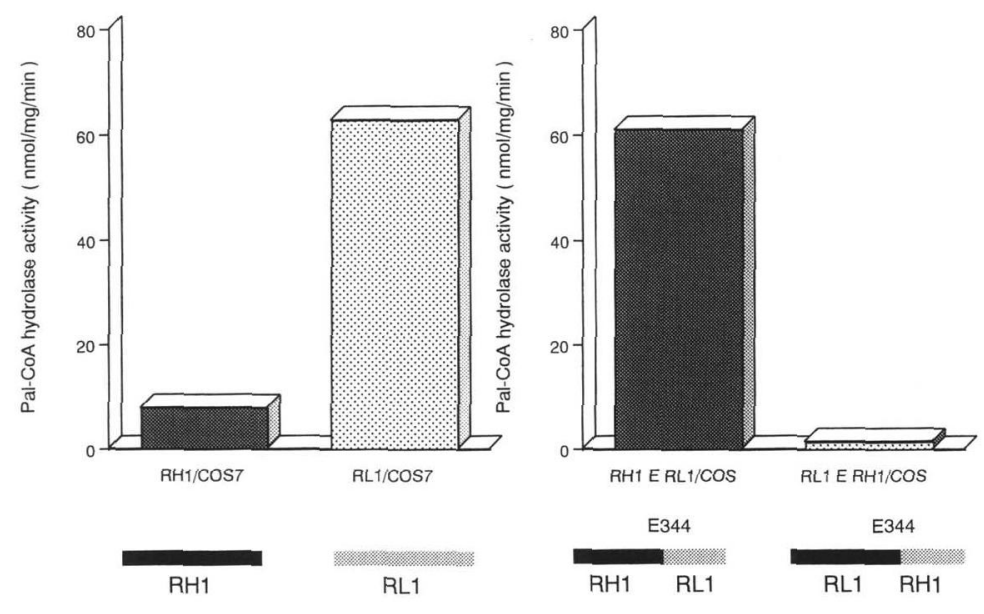

Fig. 5 Comparison of palmitoyl-CoA hydrolase activities between chimera carboxylesterase cDNA and wild type carboxylesterase cDNA expressed in COS7 cell

した (Fig. 5)。この結果から, CES RL1の Pal-CoA に対する特異性は334位のグルタミン酸より C一未端側 のアミノ酸配列に依存することが示され，この領域に基 質結合部位が存在する可能性が強く示唆された. 今後, さらにこの領域に存在すると考えられる基質結合部位に ついて詳細に検討する必要があると考えられる.

\section{構造的特性に基づいたカルボキシルエステラ 一ゼの分類}

CESの分類に関しては1983 年にWalker と


も EC 3.1.99.1 から EC 3.1.99.3 までの分類が提唱され ている.しかしながらこれらの分類はすべて CESの cDNA クローニングが行われる前の分類で, 本酵素に 対する情報の欠除からかなり偏ったものになっている. そこで, 我々はAnn. Rev. Pharmacol. Toxicol.2)の中で, CES の新しい分類法について提唱した．この分類は Table IV に示したように，ヒト HU1 との相同性に基づい てCES をCES1 から CES4 をでの 4 つのファミリーに 分類したものであるが，興味深いことに Fig. 6 に示し た分子進化の系統樹の結果と驚くほど良く一致してお り，この方法によりCES の分類は可能であると考えら れる.この中でも CES1B ファミリーは生体内基質であ る長鎖アシル $\mathrm{CoA}$ の水解に特異性が高く, また CES1A3 は小胞体膜に存在するアクセサリータンパク であるエガシンとして $\beta$ タグルクロニダーゼに結合する ことが明らかとなっている.さらにCES1Cファミリー はすべて分必型のCES であることなど, 明確にCES の特性の差暴で分類されている，また，CES2 ファミリ 一に関する情報は少なかったが，最近ヒト肝から hCE2 がクローニングされ44), また同時にヒト小腸から もほほ同じ配列の HSICE ${ }^{45}$ )がクローニングされたこと
からこれらのCES アイソザイムは肝と小腸の両方に 発現している可能性が示された. 著者の研究室において も, 哺乳動物およびヒト腸管には等電点の低いCES ア イソザイムが発現していることを見いだしているが，こ れらのアイソザイムは CES2 ファミリーに属している ものと考えられる．また，ラット以外の哺乳動物では肝 と小腸に常在型として発現しているのに対し，ラット肝 では誘導型であり, ペルオキシソーム増殖薬, グルココ ルチコイドやフェノバルビタール投与により初めて発現 が認められるCESアイソザイムである25). Table I に 示したアイソザイムの中で, CES2 ファミリーに属する と考光られるアイソザイムはラットRL4, Rllec，マウ ス ML3，ウサギRB2，カニクイザル MK2，アカゲザ ル RMK2 およびヒト HU3 で, PAGE-エステラーゼ活 性染色法により確認したところいずれのアイソザイムも 小腸に発現しているCES と移動度が一致した。しかし ながら，ファミリ一内に打いても相同性と基質特異性が 一致しない場合もあることから, 今後, さらに各ファミ リーごとの特異基質の探索や，新しくクローニングされ たCESを加えることにより，分類を着実に行っていき たい.

\section{ヒトカルボキシルエステラーゼの個人差}

これまでCES の哺乳動物種間での差異について多く の紙面をさいてきたが，実際に医薬品を開発する過程 で，実験動物のデーターをヒトに外捙する場合と同様に 困難な問題はヒトにおける個人差の問題である.そこで 実際にヒト肝の CES について, 個人差も含めて詳細な 検討を行った。 まず，29個体のヒト肝よりミクロゾー ム画分を調製し，8種類のエステルおよびアミド結合を 有する基質を用いてエステラーゼ活性を調べたところ， 個体間で著しい差異が認められた ${ }^{13)}$ 。個体間での差異 
Table IV Classification and nomenclature for the carboxylesterases

\begin{tabular}{|c|c|c|c|c|}
\hline $\begin{array}{l}\text { Enzyme } \\
\text { name }\end{array}$ & $\begin{array}{l}\text { Gene } \\
\text { symbol }\end{array}$ & $\begin{array}{l}\text { Trivial } \\
\text { name }\end{array}$ & Species & Homology \\
\hline \multirow{31}{*}{$\begin{array}{l}\text { Carbox- } \\
\text { ylesterase }\end{array}$} & \multirow[t]{6}{*}{ CES $1 \mathrm{~A} 1$} & HU1 & Human & 100.0 \\
\hline & & $\mathrm{hCE}$ & Human & 99.8 \\
\hline & & $\begin{array}{l}\text { Human } \\
\mathrm{CE}\end{array}$ & Human & 99.7 \\
\hline & & $\mathrm{CE}$ & Human & 99.7 \\
\hline & & $\begin{array}{l}\text { Macro- } \\
\text { phage }\end{array}$ & Human & 99.6 \\
\hline & & $\mathrm{hCEv}$ & Human & 99.5 \\
\hline & \multirow[t]{6}{*}{ CES $1 \mathrm{~A} 2$} & D1 & Dog & 78.0 \\
\hline & & Rabbit 1 & Rabbit & 77.6 \\
\hline & & MH1 & Mouse & 77.6 \\
\hline & & pI 6.1 & Rat & 77.1 \\
\hline & & $\begin{array}{l}\text { Hydrolase } \\
\text { A }\end{array}$ & Rat & 77.1 \\
\hline & & RH1 & Rat & 77.1 \\
\hline & \multirow[t]{2}{*}{ CES $1 \mathrm{~A} 3$} & Egasyn & Mouse & 75.5 \\
\hline & & $\begin{array}{l}\text { ES3 } \\
\text { (Egasyn) }\end{array}$ & Rat & 74.6 \\
\hline & \multirow[t]{5}{*}{ CES1B } & ES4 & Rat & 67.8 \\
\hline & & $\underset{\text { C }}{\text { Hydrolase }}$ & Rat & 67.1 \\
\hline & & $\begin{array}{l}\text { Hydrolase } \\
\text { B }\end{array}$ & Rat & 66.7 \\
\hline & & RL1 & Rat & 65.7 \\
\hline & & ML1 & Mouse & 63.0 \\
\hline & \multirow[t]{6}{*}{ CES1C } & $\mathrm{E} 1(\mathrm{sec})$ & Rat & 69.2 \\
\hline & & Rat CE & Rat & 69.2 \\
\hline & & $\begin{array}{l}\text { Hydrolase } \\
\text { S }\end{array}$ & Rat & 69.2 \\
\hline & & RS1 & Rat & 68.6 \\
\hline & & Es-N & Mouse & 64.9 \\
\hline & & MS1 & Mouse & 64.9 \\
\hline & \multirow[t]{4}{*}{ CES2 } & HCE2 & Human & 47.0 \\
\hline & & $\mathrm{HSiCE}$ & Human & 47.0 \\
\hline & & Rabbit 2 & Rabbit & 46.7 \\
\hline & & AT -51 & Hamster & 45.5 \\
\hline & CES3 & $\mathrm{ES}$-male & Mouse & 39.8 \\
\hline & CES4 & $46.5 \mathrm{kDa}$ & Human & 31.3 \\
\hline
\end{tabular}

は基質により異なっていたが，最大値と最小値を比較し たところ 8 倍から 40 倍もの差異が得られた。また，実 際に臨床で用いられているプロドラッグとして抗癌剂で ある CPT-11 水解活性について同様の検討を行ったと ころ，他の基質と同様な著しい個体差が認められた。こ のような個体間の変動については，1）遺伝多型による アイソザイムの欠損，2）個体間でのアイソザイムの発 現量の違い，3）剖検材料を用いているので死後経過時 間の差異，4）性差や年齢などの要因，5）死因および 投与された薬物の違い，などが考光られるので，これら の点を考慮してさらに詳細な検討を行った，我々はこれ までヒト肝ミクロゾーム画分より 3 種のエステラーゼ アイソザイム（HU1, HU2, HU3）を精製し諸性質につ

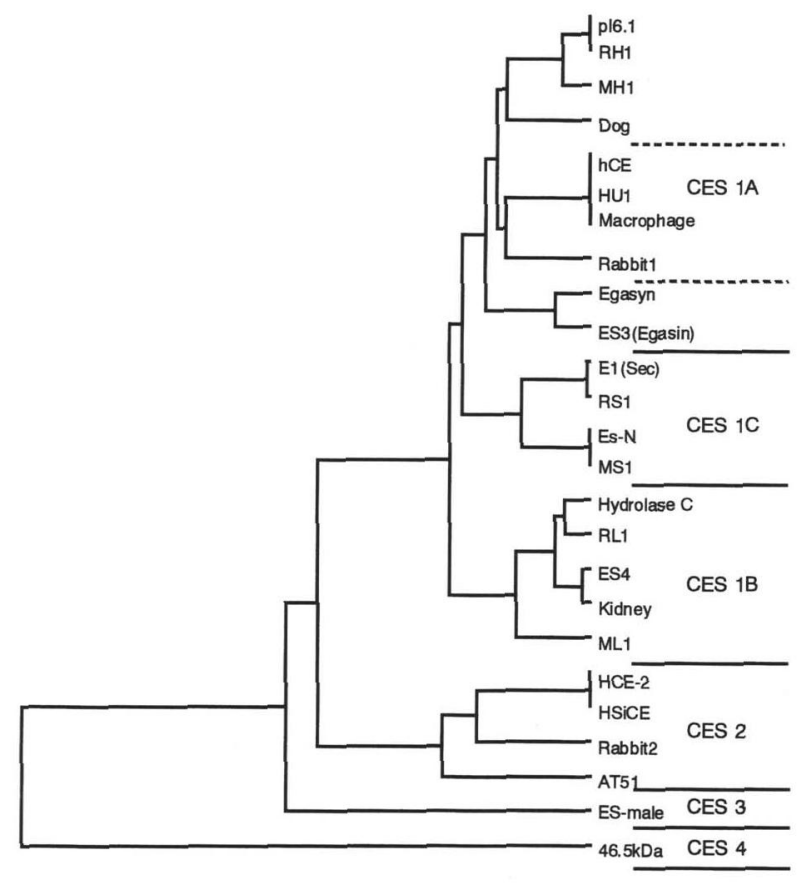

Fig. 6 Phylogenetic tree of the carboxylesterase superfamily. Each trivial names appears in Table 3

いて比較検討してきたので，これらのアイソザイムの性 質の差異に基づいて遺层多型を調べたところ，用いた 29個体の間では明確なアイソザイムの欠損は認められ なかった ${ }^{13)}$.さらに，エステラーゼの発現量の差異を 調べる目的でヒト肝ミクロゾームのアイソザイム含量を 抗 HU1 抗体を用いたWestern blot 法により調べたと ころ，Fig. 7 に示したように酵素含量の著しい差異が 認められた。この HU1 抗体は HU1, HU2 の両アイソ ザイムに交叉性を示すことから，エステラーゼ活性の個 体間での差異はエステラーゼの発現量の違いに基づいて いる可能性が考えられた。 屯た，この29個体のヒト肝 は剖検で得られたサンプルを用いているので, 死後経過 時間に伴いエステラーゼの失活や分解が考えられた。 そ こで死後経過時間とエステラーゼ活性の相関について検 討したところ，死後経過時間とエステラーゼ活性には明 確な相関関係は認められなかった。さらに性別による違 いについても調べたところ，いずれの基質を用いた場合 でも性差は認められなかった，また年龄についても検討 したところ，年齢とエステラーゼ活性の間に関しても相 関関係は認められなかった。一方，これら29個体につ いて死因とエステラーゼ活性の間の相関を検討したとこ ろ，特にアルコール性肝障害で死亡した場合にはエステ ラーゼ活性が低下する傾向を示したが，他の死因との間 には明確な関係は認められなかった，以上のことから。 ヒト肝ミクロゾーム画分のエステラーゼ活性の個体間で の差異の主要な原因は CES の発現量に基づく可能性が 示唆された. 


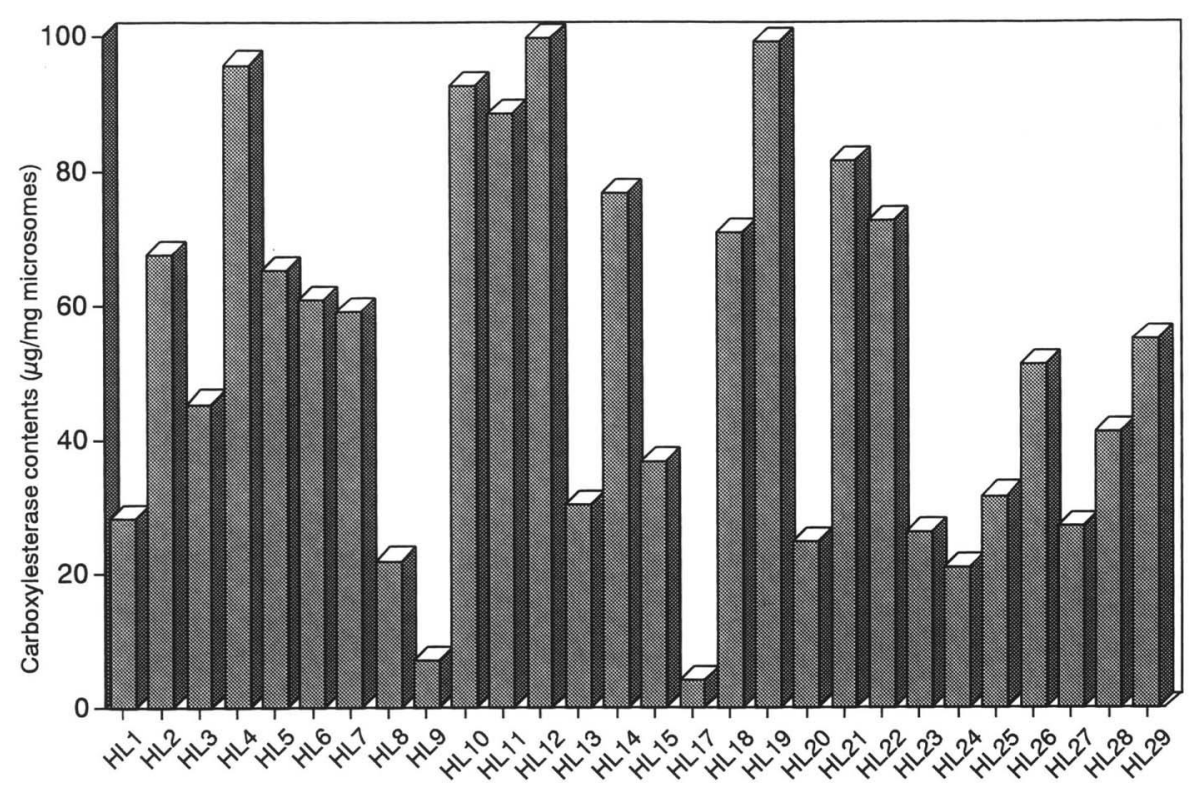

Fig. 7 Immunoblot analysis of carboxylesterase HU1 contents in various human liver microsomes



Fig. 8 Structure of the stranscriptional regulatory element of human liver carboxylesterase gene

そこで，ヒト肝 CES アイソザイム HU1 cDNA を元 に作製したプローブを用いてヒトゲノム DNA ライブラ リーよりスクリーニングを行い，ヒトCES ゲノム DNA クローン H2A を得た. さらにこの H2A の塩基配 列を解析したところ, CES の Exon1 抢よび5’上流の シス領域と考えられる配列を含んでいることが明らかと なった．そこで約 $1 \mathrm{~kb}$ 上流までの塩基配列について解 析したところ, Sp1 を含む多くの転写因子の結合配列の 存在が明らかとなり,この領域が転写調節領域である可 能性が示唆された（Fig. 8)。ささらに115名の健常人ボラ ンティアの末梢血より抽出したゲノム DNA を材料に用 いてヒト CES の Exon1 の上流約 $1 \mathrm{~kb}$ の部分を PCRSSCP 法を用いて検討した. その結果, 遺伝子の一次構 造に差異が認められ，さらに塩基配列の解析を行ったと ころ個人差が確認された。特に 5 ' 上流の転写因子結合 部位に差異が認められたことから，この領域の遺厷子多 型が CES 発現量の個人差に関与している可能性が示唆 された. 以上の結果より, ヒト CES 遺伝子のシス領域 々考えられる 5 , 上流領域に遺伝子多型の存在が確認さ れたので, この領域の差異が $\mathrm{CES}$ 発現量の個人差の原
因である可能性が考えられ, ヒト肝 CES の発現量の個 人差の一部はこの領域の遺厷子多型が原因となっている ことが示唆された。

\section{おわりに}

近年, 様々なエステルおよびアミド型のプロドラッグ の開発に伴い哺乳動物およびヒトの CES の種差が問題 になってきている．著者は, 実験動物のデーターのヒト への外挿という観点から研究を始めたが，いつの間にか 酵素精製から cDNA クローニング, さらにはゲノム DNA のクローニングまで手を広げてきた．しかしなが らCES においてはいまだにヒトのモデルとなる実験動 物は見つかっておらず, 分子構造が明らかとなればなる ほどヒトと実験動物の種差は大きくなっており, 実験動 物から得られたデーターのヒトへの外挿を困難にしてい る. また最後に述べたように, 薬物の薬効や生体内動態 を考慮した場合, ヒトに抢いてはCES の発現量の個人 差が大きな問題となっているので, ヒト末梢血がら得ら れたゲノムの解析により発現量を推定する方法を近いう ちに確立したい。さらに, 本稿でも少し触れたが CES の基質結合部位に関してもさらに詳細な検討を行い, 特 にCES の基質結合領域の分子進化を通して本酵素の機 能的役割を解明していきたい。

謝 辞 本研究は千葉大学薬学部薬物学研究室での研究テー マに端を発し, その後, 東京薬科大学第 1 薬理学教室, 臨床生 化学教室在職時に研究を発展させ, さらに千葉大学薬学部薬物 学研究室に戻ってから飛躍的に発展させたものです.この間, 千葉大学薬学部 $\rightarrow$ 東京薬科大学薬学部 $\rightarrow$ 千葉大学薬学部 23 回 にわたり研究の機会とご指導を賜りました元千葉大学教授佐藤 
哲男先生 (現昭和大学薬学部客員教授, 霊長類機能研究所所長) に厚く御礼申しあげますとともに, 千葉大学薬学部薬物学研究 室において本研究の機会を賜りました故北川晴雄教授，ならび にペルオキシソームの世界に触れさせていただき研究の機会と 助言を賜りました東京薬科大学薬学部教授須賀哲弥先生, ま た，臨床の点から新しい研究の世界を広げてくださり研究の機 会と助言を賜りをした千葉大学薬学部教授千葉 寛先生に厚く 御礼申し上げをす．さらに，紙面の都合により名前を省略させ ていただきますが，本研究の遂行にあたり，共同研究者として 研究の発展に多大なる貢献をいただきました東京薬科大学第 1 薬理学教室, 臨床生化学教室扔よび千葉大学薬学部薬物学研究 室の大学院生, 4 年生の皆様に心より感謝いたします.

\section{文献}

1) Satoh, T. and Hosokawa, M: The mammalian carboxylesterases: From molecules to functions. Ann. Rev. Pharmacol. Toxicol., 38: 257-288, 1998.

2) Hosokawa M, Maki T, Satoh T: Multiplicity and regulation of hepatic microsomal carboxylesterases in rats. $\mathrm{Mol}$ Pharmacol. 31: 579-84, 1987.

3) Hosokawa M, Maki T, Satoh T: Characterization of molecular species of liver microsomal carboxylesterases of several animal species and humans. Arch Biochem Biophys. 277: 219-27, 1990.

4) Mentlein R, Suttorp M, Heymann E: Specificity of purified monoacylglycerol lipase, palmitoyl-CoA hydrolase, palmitoyl-carnitine hydrolase, and nonspecific carboxylesterase from rat liver microsomes. Arch Biochem Biophys. 228: 230-46, 1984.

5) Satoh T: Role of carboxylesterases in xenobiotic metabolism. Reviews in Biochemical Toxicology, in Bend JR, Hodgson E, Philpot RM (eds), 155-81, 1987. New York: Elsevier.

6）細川正清 : 哺乳動物およびヒト肝 CES の機能的役割の差 異. 薬物動態 5: 185-195, 1990.

7) Takayama H, Watanabe A, Hosokawa M,. Chiba K, Satoh T, Aimi N: Synthesis of new class of camptothecin derivatives, the long-chain fatty acid esters of 10-hydroxycamptothecin, as a potent prodrug candidate, and their in vitro metabolic conversion by carboxylesterases. Bioorg. Medicinal Chem. Letter 8: 415-418, 1998.

8) Kusano K, Seko T, Tanaka S, Shikata Y, Ando T, Ida S, Hosokawa M, Satoh T, Yuzuriha T and Horie T: Purification and characterization of monkey liver amidohydrolases and it's relationship to a metabolic polymorphism of E6123, a platelet activating factor receptor antagonist. Drug. Metab. Dispos., 24: 1186-1191, 1996.

9) Dixon M. Webb, EC: Enzymes, 3rd edition, Academic Press, New York, 1979.

10) Ishihara, $K$, Hosokawa, M. Satoh T: Tissue specific distribution of carboxylesterase isozymes in rat. J. Toxicol.Sci., (suppl.,) 12: 389, 1987.

11) Yamada T, Kawaguchi N, Hosokawa M, Satoh T: Localization of an isoform of carboxylesterase in rat brain differs from that in human brain. Brain Res. 674: 175-9, 1995.

12) Yamada T, Hosokawa M, Satoh T, Moroo I, Takahashi M,
Akatsu H, Yamamoto T: Immunohistochemistry with an antibody to human liver carboxylesterase in human brain tissues. Brain Res. 658: 163-7, 1994.

13) Hosokawa M, Endo $Y$, Fujisawa M, Hara $S$, Iwata N, Sato $\mathrm{Y}$, Satoh T: Interindividual variation in carboxylesterase levels in human liver microsomes. Drug. Metab. Dispos. 23: 1022-1027, 1995.

14) Satoh T, Hosokawa M: Molecular aspects of carboxylesterase isoforms in cimparison with other esterases. Toxicology Letters. 82: 439-445, 1995.

15) Satoh T, Hosokawa M, Atsumi R, Suzuki W, Hakusui H, Nagai E: Metabolic activation of CPT-11, 7-ethyl-10-[4(1-piperidino)-1- piperidino]carbonyloxycamptothecin, a novel antitumor agent, by c arboxylesterase. Biol Pharm Bull. 17: 662-4, 1994.

16) Maki T, Hosokawa M, Satoh T, Sato K: Changes in carboxylesterase isoenzymes of rat liver microsomes during hepatocarcinogenesis. Jpn J Cancer Res. 82: 800-6, 1991.

17) Hosokawa $M$, Satoh $T$, Ohkawara $S$, Ohmori $S$, Igarashi $\mathrm{T}$, et al: Gonadal hormone-induced changes in hepatic microsomal carboxylesterase in rats. Res Commun Chem Pathol Pharmacol. 46: 245-58, 1984.

18) Hosokawa M, Satoh T, Ohkawara S, Ohmori S, Igarashi $\mathrm{T}$, et al: Effects of adrenalectomy on gonadal hormone-induced changes in hepatic microsomal carboxylesterase activities in rats. Res Commun Chem Pathol Pharmacol. 47: 285-8, 1985.

19) Hosokawa M, Satoh T: Effects of hypophysectomy and pituitary hormones on hepatic microsomal c arboxylesterase isozymes in male rats. Res Commun Chem Pathol Pharmacol. 62: 279-88, 1988.

20) Hosokawa M, Suga T, Satoh T: Differnces in the regulation of carboxylesterase isozymes in rat liver microsomes. Biol. Chem. Hoppe-Seyler. 370: 983-984, 1989.

21) Hosokawa M, Maki T, Satoh T: Differences in the induction of carboxylesterase isozymes in rat liver microsomes by xenobiotics. Biochem Pharmacol. 37: 2708-11, 1988.

22) Hosokawa M, Hattori K, Satoh T: Differential responses of rat hepatic microsomal carboxylesterase isozymes to glucocorticoids and pregnenolone 16 alpha-carbonitrile. Biochem Pharmacol. 45: 2317-22, 1993.

23) Hosokawa M, Satoh T: Differences in the induction of carboxylesterase isozymes in rat liver microsomes by perfluorinated fatty acids. Xenobiotica. 23: 1125-33, 1993.

24) Hosokawa M, Hirata K, Nakata F, Suga T, Satoh T: Species differences in the induction of hepatic microsomal carboxylesterases caused by dietary exposure to di (2-ethylhexyl)phthalate, a peroxisome proliferator. Drug Metab Dispos. 22: 889-94, 1994.

25) Derbel M, Hosokawa M, Satoh T: Differences in the induction of carboxylesterase RL4 in rat liver microsomes by various perfluorinated fatty acids, metabolically inert derivatives of fatty acids. Biol. Pharm. Bull. 19: 765-67, 1996.

26) Takagi $Y$, Morohashi K, Kawabata S, Go M, Omura T: Molecular cloning and nucleotide sequence of cDNA of microsomal carboxyesterase $\mathrm{E} 1$ of rat liver. $J$ Biochem. 104: 801-6, 1988.

27) Long RM, Satoh H, Martin BM, Kimura S, Gonzalez FJ, Pohl LR: Rat liver carboxylesterase: cDNA cloning, sequencing, and evidence for a multigene family. Biochem Biophys Res Commun. 156: 866-73, 1988. 
28) Yan B, Yang D, Brady M, Parkinson A: Rat kidney carboxylesterase. Cloning, sequencing, cellular localization, and relationship to rat liver hydrolase. J Biol Chem. 269: 29688-96, 1994.

29) Yan B, Yang D, Brady M, Parkinson A: Rat testicular carboxylesterase: Cloning, cellular localization, and relationship to liver hydrolase A. Arch Biochem Biophys. 316: 899908, 1995.

30) Yan B, Yang D, Bullock P, Parkinson A: Rat serum carboxylesterase. Cloning, expression, regulation, and evidence of secretion from liver. J Biol Chem. 270: 19128-34, 1995.

31) Robbi M, Beaufay H, Octave JN: Nucleotide sequence of cDNA coding for rat liver pI 6.1 esterase (ES-10), a carboxylesterase located in the lumen of the endoplasmic reticulum. Biochem J. 269: 451-8, 1995.

32) Robbi M, Beaufay $\mathrm{H}$ : Cloning and sequencing of rat liver carboxylesterase ES-3 (egasyn). Biochem Biophys Res Commun. 203: 1404-11, 1994.

33) Robbi M, Van Schaftingen E, Beaufay H: Cloning and sequencing of rat liver carboxylesterase ES-4 (microsomal palmitoyl-CoA hydrolase). Biochem J. 313: 821-6, 1996.

34) Ovnic M, Tepperman K, Medda S, Elliott RW, Stephenson DA, et al: Characterization of a murine cDNA encoding a member of the carboxylesterase multigene family. Genomics. 9: 344-54, 1991.

35) Ovnic M, Swank RT, Fletcher C, Zhen L, Novak EK, et al: Characterization and functional expression of a cDNA encoding egasyn (esterase-22): the endoplasmic reticulumtargeting protein of beta-glucuronidase. Genomics. 11: 956-67, 1991.

36) Aida K, Moore R, Negishi M: Cloning and nucleotide sequence of a novel, male-predominant carboxylesterase in mouse liver. Biochim Biophys Acta. 1174: 72-4, 1993.

37) Sone T, Isobe M, Takabatake E, Wang CY: Cloning and sequence analysis of a hamster liver cDNA encoding a novel putative carboxylesterase. Biochim Biophys Acta. 1207: 138-42, 1994.

38) Kroetz DL, McBride OW, Gonzalez FJ: Glycosylation-dependent activity of baculovirus-expressed human liver $\mathrm{c}$ arboxylesterases: cDNA cloning and characterization of two highly similar enzyme forms. Biochemistry. 32: 11606-17, 1993.

39) Shibata F, Takagi $Y$, Kitajima M, Kuroda T, Omura T: Molecular cloning and characterization of a human carboxylesterase gene. Genomics. 17: 76-82, 1993.

40）細川正清, 鈴木香代子, 千葉 寛, 佐藤哲男：アシル $\mathrm{COA}$ 水解活性を触媒するビーグル犬肝カルボキシルエス テラーゼの cDNA クローニング. 生化学 68: 886, 1996.

41) Cygler M, Schrag JD, Sussman JL, Harel M, Silman I, Gentry MK, Doctor BP: Relationship between sequence conservation and three-demensional structure in a large family of esterases, lipases, and related protein. Protein Science. 2: 366-382, 1993.

42) Ozols J: Isolation, properties, and the complete amino acid sequence of a second form of $60-\mathrm{kDa}$ glycoprotein esterase. J. Biol. Chem. 264: 12533-12545, 1989.

43) Walker $\mathrm{CH}$, Mackness MI: Esterases: Problems of identification and classification. Biochem. Pharmacol. 32: 326569, 1963

44) Pindel EV, Kedishvili NY, Abraham TL, Brzezinski MR, Zhang J, Dean RA, Bostron WF: Purification and cloning of a broad substrate specificity humam liver carboxylesterase that catalyzes the hydrolysis of cocaine and heroin. J. Biol. Chem., 272: 14769-14775 (1997).

45) Schwer H, Langmann T, Daig R, Becker A, Aslanidis C, Schmitz G:Molecular cloning anhd characterization of a novel putative carboxylesterase, present in human intestine and liver. Biochem. Biophys. Res. Commun., 233:117120 (1997). 